\title{
Mutations in Symbiotic Effectiveness in Rhizobium trifolii Caused by Transforming DNA and Other Agents
}

\author{
BY JANINA KLECZKOWSKA \\ Soil Microbiology Department, Rothamsted Experimental Station, \\ Harpenden, Hertfordshire
}

(Received 11 March, 1965)

\begin{abstract}
SUMMARY
A strain of Rhizobium trifolii able to fix nitrogen in root nodules of clover plants lost its effectiveness when treated with deoxyribonucleic acid (DNA) from an ineffective strain. Attempts to transform two ineffective strains to effectiveness failed, even when the donor of DNA and the recipient strains were genetically related and apparently differed only in symbiotic property. The efficiency of transformation by DNA to ineffectiveness was compared with mutagenic and selective treatments. The results support the idea that symbiotic effectiveness involves compatability between several plant and bacterial factors, changes in any one of which makes the bacterium ineffective.
\end{abstract}

\section{INTRODUCTION}

Individual strains of nodule Rhizobium are usually stable, maintaining their morphological, serological, symbiotic and other features unaltered during many years of cultivation on artificial media. New properties appear only rarely and irregularly. Work done on the conditions which affect the frequency and regularity of appearance of variants has often given conflicting results (see review, Kleczkowska, 1950). The treatments used by different workers do not give consistent results, and the main reason for these may be that different bacterial strains behave differently. The work described in the present paper was done to see whether deoxyribonucleic acid (DNA) of the bacteria acts as a transforming factor and can change symbiotic properties. When DNA was found to do so its efficiency was compared with the results of previous work (Kleczkowska, 1950; Gupta \& Kleczkowska, 1961) where, due to mutagenic (u.v. irradiation) and selective agents (streptomycin or bacteriophage), similar genetic mutants were obtained.

\section{METHODS}

Three strains of Rhizobium trifolii Dung. were used: strain A 121111, which is effective in nitrogen fixation, and strains 12 and HKc which are ineffective on the host plant, Trifolium pratense $\mathrm{L}$. These strains had been maintained over a long period on yeast water agar medium and had often been passed through clover plants without showing any genetic changes. Strain $\mathrm{f12}$ is a stable ineffective variant of strain A121111 (Nutman, 1946), from which it cannot be distinguished culturally or serologically. Strain HKc differs serologically from A 121111; strains A121111 and f12 are both susceptible to bacteriophage A121111, to which strain HKC is resistant. The proportion of phage-resistant bacteria in cultures of these organisms never exceeded $0.01 \%$ and was usually less than $0.001 \%$. 
The methods of obtaining phage-resistant and streptomycin-resistant mutants, and also the technique of isolating surviving bacteria after exposure to ultraviolet (u.v.) radiation were described previously (Kleczkowska, 1950; Gupta \& Kleczkowska, 1961). The proportion of streptomycin-resistant bacteria in a culture of strain A 121111 is about $0.00001 \%$. Strain A 121111 was exposed to u.v.-radiation so that the proportion of surviving bacteria was about $0.5 \%$. The ineffective strains f12 and HKC were not tested with streptomycin or u.v.-radiation. Preparations of DNA were obtained from large quantities of strains A 121111 and HKC grown either on agar medium or in a chemostat. For continuous culture (apparatus described by Skinner \& Walker, 1962) a liquid medium of the following composition was used: 0.5 g. $\mathrm{KH}_{2} \mathrm{PO}_{4} ; 0.1 \mathrm{~g}$. $\mathrm{MgSO}_{4} \cdot 7 \mathrm{H}_{2} \mathrm{O} ; 0.5 \mathrm{~g}$. $\mathrm{CaCl}_{2} \cdot 6 \mathrm{H}_{2} \mathrm{O} ; 10 \mathrm{~g}$. sucrose; $100 \mathrm{ml}$. yeast water extract; $1 \mathrm{ml} .0 \cdot 1 \mathrm{~N}-\mathrm{HCl} ; 900 \mathrm{ml}$. water; adjusted to $\mathrm{pH} \mathrm{6.8-6.9}$ with $5 \%(\mathrm{w} / \mathrm{v}) \mathrm{Na}_{2} \mathrm{CO}_{3}$. Growth was at $27^{\circ}$ and the steady-state numbers of bacteria were $13 \times 10^{8} / \mathrm{ml}$. The bacteria were separated in a Sharples centrifuge.

The agar medium (Kleczkowska, 1950) was distributed in $150 \mathrm{ml}$. portions in $16 \mathrm{oz}$. medicine bottles and allowed to set horizontally. Each bottle was inoculated with $3 \mathrm{ml}$. of a $48 \mathrm{hr}$ liquid culture and incubated for 7 days at $28^{\circ}$; the bacteria were then washed from the surface of the agar with sterile saline solution and centrifuged down. Although both methods were satisfactory, strain A121111 grew better on the agar medium.

DNA was prepared from the bacteria by the method described by Balassa (1960). It was finally precipitated with ethanol, centrifuged down, dissolved in sterile saline and kept at $-20^{\circ}$ until needed. The $u$.v.-absorption spectrum of the preparations differed from that of thymus DNA by showing more absorption at wavelengths shorter than $260 \mathrm{~m} \mu$, indicating that they were probably contaminated with protein. The concentration of DNA was estimated colorimetrically by using diphenylamine in acetic acid (Dische, 1930), against a standard commercial preparation of thymus DNA.

For transformation tests the DNA preparations were added to sterile liquid media to a concentration of $0.025-0.1 \mathrm{mg} . / \mathrm{ml}$. and the mixture then inoculated with the bacteria. The cultures were incubated for times $\left(4,14,21\right.$ days) at $28^{\circ}$; single colonies were then isolated by the plate dilution technique. Since the time of incubation did not affect the results, the results of the different times have been treated together. Each colony isolate after treatment was tested for effectiveness in nitrogen fixation on four sterile seedlings of red clover grown singly in tubes on a nitrogen-deficient agar medium (Nutman, 1946). The plants were allowed to grow for about 3 months until control plants inoculated with untreated strain A121111 had 8 true leaves. At the end of a test plants were classified as to effectiveness. The effective class included a small proportion of plants that were intermediate in size, but these were clearly distinguished from ineffective plants which made no better growth than uninoculated controls.

\section{RESULTS}

Table 1 shows the effect on strain A121111 of the selective and mutagenic treatments in terms of the distribution of plant response in sets of four test plants. The results with the control untreated bacteria of strain a121111 confirmed Nutman's (1954) observations that a proportion of clover plants did not fix nitro- 
gen with this strain. That this reflects heterogeneity in the plant population and not the bacterial colonies is concluded from the fact that plants which did not fix nitrogen were distributed randomly among the sets of four plants inoculated with different bacterial colonies. This is shown by the following statistical examination. A total of 680 plants in 170 sets of four were inoculated with untreated control bacteria of which 48 plants did not respond, so that the probability of a plant not responding was $P=48 / 680=0.0 \%$. With a random distribution the expected numbers of sets of four plants in which $0,1,2,3$ and 4 plants did not respond are

Table 1. Effect of various mutagenic and selective treatments on symbiotic effectiveness on red clover in Rhizobium trifolii strain $A 121111$

\begin{tabular}{|c|c|c|c|c|c|c|}
\hline \multirow{2}{*}{ Treatment } & \multirow{2}{*}{$\begin{array}{l}\text { Total } \\
\text { numbers } \\
\text { of colonies } \\
\text { tested }\end{array}$} & \multicolumn{5}{|c|}{ Response in four test plants } \\
\hline & & $\begin{array}{l}\text { All four } \\
\text { effective }\end{array}$ & $\begin{array}{l}\text { Three } \\
\text { effective } \\
\text { Imber of e }\end{array}$ & $\begin{array}{l}\text { Two } \\
\text { effective } \\
\text { lonies in e }\end{array}$ & $\begin{array}{l}\text { One } \\
\text { effective } \\
\text { ch response }\end{array}$ & $\begin{array}{l}\text { All four } \\
\text { ineffective } \\
\text { e }\end{array}$ \\
\hline Control (untreated) & 170 & 181 & 35 & 5 & 1 & $\mathbf{0}$ \\
\hline Streptomycin & 28 & 21 & $\mathbf{5}$ & 1 & $\mathbf{0}$ & 1 \\
\hline U.v. irradiation & 23 & 14 & 6 & 1 & $\mathbf{0}$ & 2 \\
\hline Phage A 121111 & 68 & 22 & 6 & 10 & 8 & 22 \\
\hline DNA from strain aKc & 170 & 104 & 44 & 5 & $\mathbf{3}$ & 14 \\
\hline $\begin{array}{l}\text { DNA from strain } \\
\text { HKC + phage } \\
\text { A } 121111\end{array}$ & 20 & 3 & 0 & 1 & 4 & 12 \\
\hline
\end{tabular}

Table 2. A comparison of observed results of inoculating 170 sets of four red clover plants with different colonies isolated from untreated strain ${ }_{1} 121111$ of Rhizobium trifolii (control) with values expected on the assumption of random distribution of plants which responded ineffectively

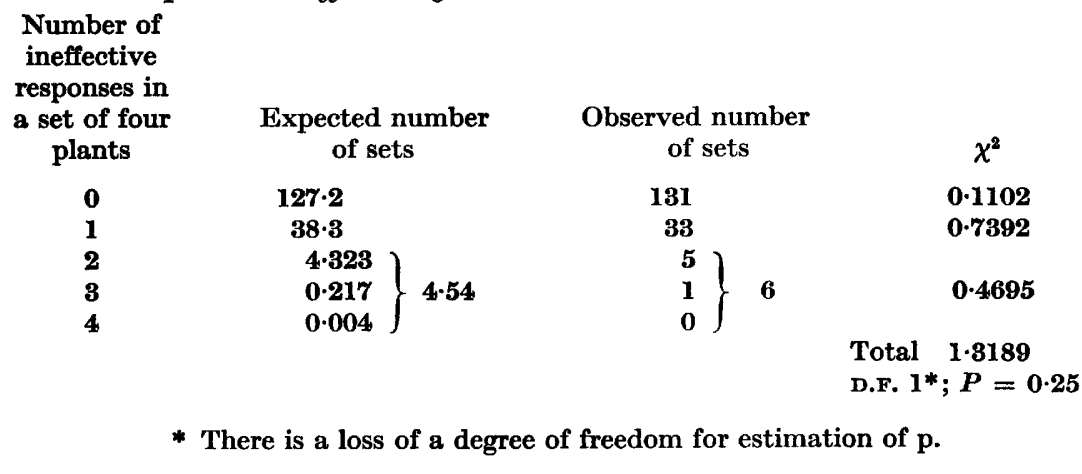

given by the successive terms of the expanded binomial $(0 \cdot 93+0 \cdot 07)^{4}$ multiplied by 170. Table 2 compares the expected numbers with those obtained. The $\chi^{2}$ test shows that the probability of deviations from expectation exceeding by chance those observed was about $\mathbf{0 \cdot 2 5}$. The agreement between the observed and expected number is therefore good. The bacterial colonies can be assumed to be identical and the population of plants heterogeneous, consisting of two genotypes of plants which give different symbiotic response with the same bacterial strain. The proportion 
of plants with ineffective response is $\mathbf{0 . 0 7}$. This will be the basis for assessing the results by subjecting Rhizobium trifolii strain A121111 to the treatments indicated in Table 1.

If strain A 121111 remained unchanged the probability of a given set of four plants all failing to respond is $P_{1}=0.07^{4}=0.000024$, and consequently the probability of a set of four plants not all responding ineffectively (i.e. some or all responding effectively) is $q_{1}=1-0.07^{4}=0.999976$.

Of 28 sets of plants inoculated with colonies obtained after treating strain a 121111 with streptomycin (Table 1), the probability of at least one set of 4 plants all failing to respond effectively would therefore be $1-q_{1}{ }^{28}$ which is about 0.0015 , assuming no change in the bacterial strain. Similarly, the probability of at least two sets of 4 plants not responding out of the 23 inoculated after u.v.-irradiation, would be $1-q_{1}^{23}-23 p_{1} q_{1}^{22}$, which is about 0.0006 . These probabilities are very small and those relating to treatment with phage, DNA, or phage +DNA are infinitesimal. It can therefore be concluded that these bacterial colonies ineffective on all four test plants must almost certainly be genetically changed.

All the treatments shown in Table 1 gave ineffective mutants of strain A 121111, either by selection (bacteriophage and possibly streptomycin) or by mutagenesis (DNA from ineffective strain HKC and probably u.v.-irradiation), the highest incidence being produced by the combined treatment with DNA and bacteriophage.

Table 3. A comparison of observed results on sets of four red clover plants, some of which responded effectively, with results to be expected on the assumption that the rhizobia remained unchanged and that ineffectively responding plants were distributed at random

\begin{tabular}{|c|c|c|c|c|c|c|}
\hline \multirow{3}{*}{ Treatment } & \multirow{2}{*}{\multicolumn{2}{|c|}{$\begin{array}{c}\text { Treated } \\
\text { colonies } \\
\text { (no.) }\end{array}$}} & \multicolumn{4}{|c|}{$\begin{array}{l}\text { Numbers of ineffectively } \\
\text { responding plants in sets } \\
\text { of } 4 \text { test plants }\end{array}$} \\
\hline & & & 0 & $\mathbf{1}$ & 2 & $\mathbf{3}$ \\
\hline & 27 & $\begin{array}{l}\text { o } \\
\text { e }\end{array}$ & $\begin{array}{l}21 \\
20 \cdot 2\end{array}$ & $\begin{array}{l}5 \\
6 \cdot 1\end{array}$ & $\begin{array}{l}1 \\
0 \cdot 67\end{array}$ & $\begin{array}{l}0 \\
0.03\end{array}$ \\
\hline U.v.-irradiation & 21 & $\begin{array}{l}\mathbf{o} \\
\mathbf{e}\end{array}$ & $\begin{array}{l}14 \\
15 \cdot 7\end{array}$ & $\begin{array}{l}6 \\
4 \cdot 7\end{array}$ & $\begin{array}{l}1 \\
0.5\end{array}$ & $\begin{array}{l}0 \\
0.027\end{array}$ \\
\hline Phage A121111 & 46 & $\begin{array}{l}\mathbf{o} \\
\text { e }\end{array}$ & $\begin{array}{l}22 \\
34 \cdot 4\end{array}$ & $\begin{array}{c}6 \\
10 \cdot 4\end{array}$ & $\begin{array}{l}10 \\
1 \cdot 2\end{array}$ & $\begin{array}{l}8 \\
0.059\end{array}$ \\
\hline DNA from strain HKC & 156 & $\begin{array}{l}\mathbf{o} \\
\mathrm{e}\end{array}$ & $\begin{array}{l}104 \\
116 \cdot 7\end{array}$ & $\begin{array}{l}44 \\
35 \cdot 1\end{array}$ & $\begin{array}{l}5 \\
4 \cdot 0\end{array}$ & $\begin{array}{l}3 \\
0 \cdot 2\end{array}$ \\
\hline DNA from strain $\mathrm{HKC}+$ phage $\mathbf{A} 121111$ & 8 & $\begin{array}{l}\mathbf{o} \\
\mathbf{e}\end{array}$ & $\begin{array}{l}3 \\
6 \cdot 0\end{array}$ & $\begin{array}{l}0 \\
1.8\end{array}$ & $\begin{array}{l}1 \\
0.2\end{array}$ & $\begin{array}{l}4 \\
0 \cdot 01\end{array}$ \\
\hline
\end{tabular}

A similar procedure can be used to determine whether the bacterial colonies that gave less than four ineffectives in each set of four plants were also mutants. Table 3 compares the observed numbers of sets containing different numbers of ineffectives with those to be expected had the bacteria not been affected by the treatments. Agreement is quite good for exposure to streptomycin and u.v. irradiation. The bacterial colonies, obtained after these treatments, which were not all effective on four test plants, were therefore probably unaltered in nitrogen-fixing effectiveness. In contrast, with phage, DNA, or phage $+\mathrm{DNA}$, the observed and expected results 
disagree, indicating that the colonies that were ineffective on only a proportion of test plants had also suffered change as a result of the treatment.

The smallest difference between observed and expected numbers was with DNA, with which three sets out of $\mathbf{1 5 6}$ were ineffective in three out of four test plants. If the bacteria remained unaltered, the probability of at least three ineffectives occurring in a set of four plants would be $p_{2}=p^{4}+4 p^{3} q$, where $p=0.07$ and $q=0.93$. This gives a value of 0.0013 , so that the probability of this not occurring in a set of four plants is $q_{2}=\mathbf{0 . 9 9 8 7}$. Therefore the probability of the occurrence of at least three sets each with at least three ineffective plants in a total of 156 sets, would be

$$
1-q_{2}^{156}-156 q^{155}{ }_{2} p_{2}-\frac{1}{2}(156 \times 155) q_{2}^{154}{p_{2}}^{2},
$$

which equals 0.0012. This excludes the possibility that the bacteria used were identical with the original strain $\mathbf{A} 121111$ of Rhizobium trifolii.

Table 4. Loss of susceptibility to phage, as a result of treatment of the rhizobium strain A 121111 with $D N A$ from rhizobial strain HKC

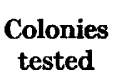

(no.)

54\{
Nitrogen fixation

$\begin{array}{ccc}\text { Effective* }^{*} & \text { Intermediate } & \text { Ineffective } \\ 21 & \dot{25} & \cdot \\ \cdot & \cdot & 8\end{array}$

Susceptibility of strain A121111 to phage

$\overbrace{\text { Susceptible }}^{\text {Resistant }}$

21

11

$\begin{array}{rr}14 & 11 \\ 5 & 3\end{array}$

* Effective response on all 4 test plants.

$\dagger$ intermediate: mixed effective and ineffective responses among 4 test plants.

¥ Ineffective response on all 4 test plants.

Ineffective and effective bacterial isolates obtained after treatments of strain A 121111 with DNA from strain HKC all agglutinated with strain A 121111 antiserum to the same end point as did unheated strain A121111 itself. Ineffectiveness was therefore transmitted independently of serological characteristics. All the isolates that retained their nitrogen-fixing effectiveness also remained susceptible to phage A 121111; but among ineffective mutants some isolates were also resistant to this phage. Table 4 shows the reaction to phage 121111 of bacterial isolates after DNA treatment. These results suggest a connexion between the characteristics, possibly through the juxtaposition of corresponding genetic loci. This is also suggested by the fact that $60 \%$ of phage-resistant mutants of strain $\mathrm{A} 121111$ are also ineffective. DNA and phage treatment together gave the very large proportion of $85 \%$ of ineffective mutants.

After phage treatment, all the surviving bacteria are at first phage-resistant, but after several subcultures on phage-free medium, most regained susceptibility to phage. Ineffective strains which regained susceptibility to phage remained ineffective. So mutation to ineffectiveness seems more stable than mutation to phage-resistance.

In contrast to strain A 121111, the ineffective strains f12 and HKC showed very little or no tendency to change their symbiotic response, although strain f12 was derived from strain $\mathrm{A} 121111$ and does not differ from it in any known feature other 
than in being ineffective. Like strain A 121111, strains f12 and HKC have been shown (Kleczkowska, 1950) to form mutants resistant to their respective phages, but none of the resistant forms of strain HKC was effective and strain f12 formed only a few effective variants after exposure to phage.

\section{DISCUSSION}

These results show great frequency and stability of the induced mutations in certain Rhizobium trifolii strains to ineffectiveness in symbiotic nitrogen fixation. Difficulties were experienced in obtaining the reverse mutation. In speculating on the significance of these relationships it should be remembered that symbiotic effectiveness is not simply a property of a bacterial strain for, as the behaviour of individual plants of the control series emphasized (Table 1), a bacterial strain effective on one host can be ineffective on another. Nutman's (1954a) studies on the inheritance of the effective response in the host and on the relationship between host genes and bacterial strain characteristics, suggest that effectiveness is an expression of compatibility between plant and bacteria. This compatibility can be broken by mutation in either host or bacterial genes. In some symbioses, changes in one of the bacterial genes suffice to interfere with the process which leads to nitrogen fixation, in others more than one gene may be involved. For example, Kleczkowska $(1957,1958)$ showed that the partially effective rhizobium strain 'Coryn' gave a mixed response in the late-flowering Montgomeryshire variety of red clover, but when tested in selected lines of the same host plant gave different responses. Some host lines did not respond at all; in some the rhizobial strain was effective; and in other host lines gave mixed responses, as in the original variety. Other effective and ineffective rhizobial strains behaved in these selected lines of clover as in unselected material, showing that the source of variation lay with the host.

The apparent irreversible nature of the change to ineffectiveness at first suggests simply a gene loss, but in view of the complex compatibility relationships between plant and bacteria there is reason to suspect other explanations. If the change from effectiveness to ineffectiveness can result from mutation in any one of several genes it will happen correspondingly more often than mutation to effectiveness in one particular gene.

The author wishes to thank Dr A. Kleczkowski, F.R.S., for statistical examination of the results, and Dr F. A. Skinner and Dr N. Walker for growing the bacterial cultures in a chemostat.

\section{REFERENCES}

Balassa, R. (1960). Transformation of strain of Rhizobium lupiny. Nature, Lond. 188, 246.

Drsche, Z. (1930). Über einige neue charakteristische Farbreaktionen der ThymonukJeinsäure und eine Mikromethod zur Bestimmung derselben in teierischen Organen mit Hilfe dieser Reaktionen. Mikrochemie, 8, 4 .

GuPta, B. M. \& KLECZKowsKa, J. (1961). A study of some mutations in a strain of Rhizobium trifolii. J. gen. Microbiol. 27, 473.

KLeCzKowsKa, J. (1950). A study of phage resistant mutants of Rhizobium trifolii. J.gen. Microbiol. 4, 298.

KLeczkowska, J. (1957). The coexistence of Rhizobium trifolii and its bacteriophage in artificial soil mixtures. Report of Roth. Exp. Sta. p. 78. 
KLeczkowska, J. (1958). Phage induced changes in Rhizobium. Report of Roth. Exp. Sta. p. 72.

Nutman, P.S. (1946). Variation within strains of clover nodule bacteria in the size of nodule produced and in the effectivity of the symbiosis. J. gen. Microbiol. 51, 411.

Nutman, P. S. $(1954 a)$. Symbiotic effectiveness in nodulated red clover. I. Variation in host and bacteria. Heredity, 8, 35.

Nutman, P. S. (1954b). Symbiotic effectiveness in nodulated red clover. II. A major gene for ineffectiveness in the host. Heredity, 8, 47.

Skinner, F. A. \& WAlker, N. (1962). Continuous culture apparatus. Arch. Mikrobiol. 38, 339. 